\title{
Successful Term Pregnancy with Placental Implantation on Uterine Septum: Case Report
}

\author{
Uterin Septum Üzerine Plasental Implantasyon ile Başarili Miadinda Gebelik: Olgu Sunumu
}

Pinar Calis, Deniz Karcaaltincaba, Aykut Ozek, Merih Bayram

Department of Obstetrics and Gynecology, Faculty of Medicine, Gazi University, Ankara, Turkey

\section{ABSTRACT}

Uterine septum is the most frequent (35-48\%) structural uterine anomaly and associated with the poorest reproductive outcome. A 24 year old, nulliparous woman (G:1 P:0) applied to our clinic for routine first trimester pregnancy ultrasound. During the examination, it was recognized that most of the placenta was implanted on the uterine septum. There was no vascularity on uterine septum in doppler ultrasound. This is extremely rare case in literature showing placental implantation on uterine septum in the first trimester and reached term with successful pregnancy outcome. In conclusion, in contrast what is believed, pregnancy with placental implantation on complete uterine septum may progress successful.

Key Words: Uterine septum, placenta, vascularization, implantation

\section{ÖZET}

Uterin septum en sık karşılaşılan (\%35-48) ve en kötü gebelik sonuçları ile ilişkili uterin anomalidir. 24 yaşında, nullipar (G:1 P:0) gebe hasta rutin ilk trimester gebelik ultrasonu için kliniğimize başvurdu. İnceleme sırasında, plasentanın büyük kısmı uterin septum üzerinde olduğu belirlendi. Uterin septumda Doppler ultrasonda kan akımı izlenmedi. Bu vaka literaturde çok nadir karşılaşılan başarıı gebelik sonucu ile sonuçlanmış, ilk trimesterde plasental implantasyonun septum üzerinde olduğu tespit edilmiş bir vakadır. Sonuç olarak, inanılanın aksine, komplet uterin septum üzerine implante olmuş plasenta ile gebelik miadına ulaaşıp, başarılı sonuçla sonuçlanabilir.

Anahtar Sözcükler: Uterin septum, plasenta, vaskularizasyon, implantasyon

Geliş Tarihi: 31.10 .2017

Kabul Tarihi: 12.01.2018

\section{INTRODUCTION}

Congenital uterine anomalies are seen 1-3\% of women, usually asymptomatic and therefore unrecognized until desire of childbearing(1). Uterine septum which is the most frequent $(35-48 \%)$ structural uterine anomaly(2) and associated with the poorest reproductive outcome(3). Even if association of septum with infertility is not statistically significant between normal controls(4), it is well recognized that it worsens obstetric outcomes with high abortion $(41.1 \%)(5)$, preterm delivery rate $(22 \%)(6,7)$ and malpresentation at delivery(4). Apart from that, approximately $15 \%-25 \%$ of spontaneous abortions are thought to be caused by uterine anomalies, and almost all are associated with uterine septum(8). The reason of spontaneous abortions is generally explained by placental implantation on septum.
The poor vascularization on uterine septum has been thought to lead to poor implantation dynamics. In the current report, we aimed to present a term pregnancy with successful outcome with placental implantation on uterine septum.

\section{CASE REPORT}

A 24 year-old, nulliparous woman (G:1 P:0) applied to our clinic for routine first trimester ultrasound. During the examination, it was recognized that most of the placenta was implanted on the uterine septum (Figure 1). Patient was unaware of uterine septum before the examination. In second trimester ultrasound, there was a deep uterine septum and minimum $1 / 3$ of the placenta was implanted on the septum (Figure 2). There was no vascularity on uterine septum in doppler ultrasound. 


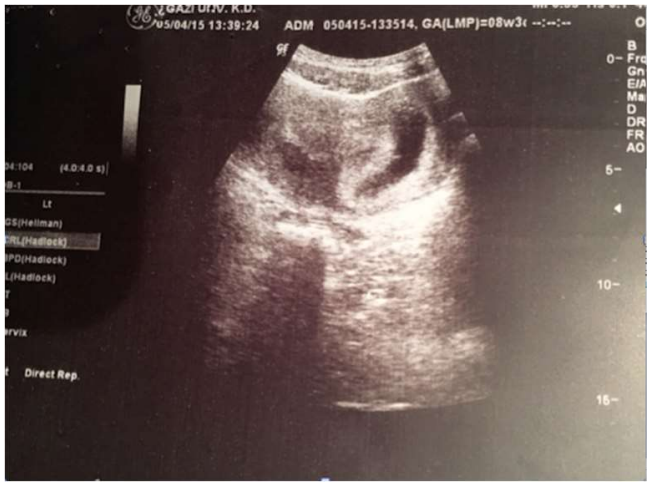

Figure 1. Ultrasound image at 8 gestational week, placenta implanted on uterine septum

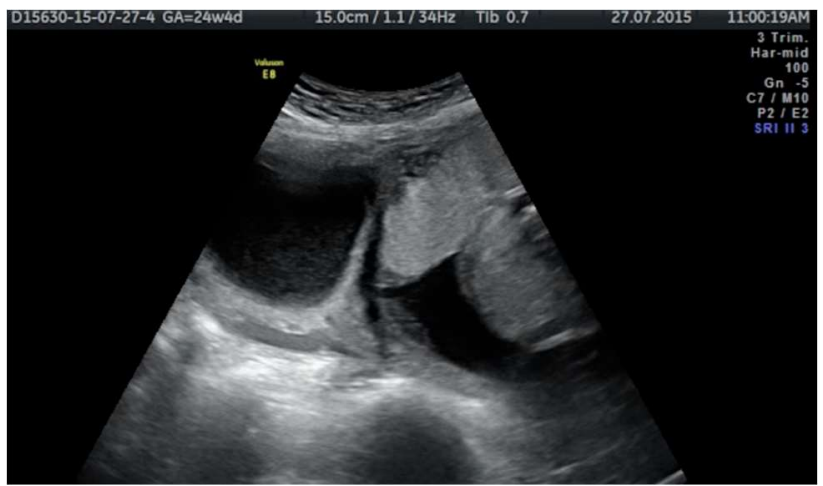

Figure 2. Ultrasound image at 24 gestational week

The pregnancy was followed especially for growth restriction with 3 weeks apart. Until the 34 week of gestation, fetus was compatible with his gestational week. From this point up to delivery, there was only one week growth delay. Placental location was followed and from the beginning of third trimester until the birth, at least $1 / 3$ of the placenta was located on uterine septum.

Patient applied to labor unit at $37+4$ gestational week with spontaneous rupture of membranes. C-section was performed because of transverse presentation. $3480 \mathrm{gr}$ baby boy was born with 5th minutes Apgar score of 10. During the operation, deep uterine septum was observed. It divided the cavity into two and half of the placenta was located on uterine septum. The adjacent uterine cavity was empty. At post operative second day patient and the baby discharged from the hospital without any complication.

\section{DISCUSSION}

The Müllerian ducts become evident in the 6- to 7-week-old embryo and ductal fusion proceeds cephalad with later resorption of the septum(9). Septate uterus results from failure of resorption of the intervening septum. In several studies, it was reported that miscarriages were generally related with the septum size(6) and the pregnancy outcomes were not usually affected if the septum was short and did not separate uterine cavity completely.
In our case, we had complete uterine septum but did not observe any poor obstetric outcome. Studies showed that histologic structure of uterine septum could affect implantation and early pregnancy process. In a study by Propst et al., the major cause of recurrent pregnancy loss for septum was implantation on poorly vascularized septum(3). Apart from that, Fedele et al also discovered maturation defects of the endometrium covering the septum(10). For these reasons, association of septum with infertility is not certain and timing of pregnancy loss before 13 weeks $25.5 \%$ and $\% 6.2$ between 14 - 22 weeks (11).

Fetal survival rate in pregnancies with septate uterus has been reported as $6 \%-28 \%(4,12)$. Those cases who survived and reached to term were supposed to have non-septal plasental implantation. Fedele L. et al studied pregnancy results in cases with complete uterine septum. In their study 8 of 12 pregnancies were ended with abortion, one had preterm birth and only three had term births. Placentas of all three term births were implanted on the lateral wall of the uterus(13). On the other hand, in our case even if placenta was implanted mostly on the septum in the first trimester, at least a $1 / 3$ of it in the second and third trimester, the pregnancy was ended at term ( $37+4$ gestational week).

As a conclusion; pregnancy with placental implantation on complete uterine septum may progress successfully. When septum was diagnosed during the pregnancy, even if placental implantation is on the septum, patient should be informed that it may not cause a pregnancy complication.

\section{Conflict of interest}

No conflict of interest was declared by the authors.

\section{REFERENCES}

1. Acien P. Incidence of Mullerian defects in fertile and infertile women. Hum Reprod. 1997;12:1372-6.

2. Heinonen PK. Reproductive performance of women with uterine anomalies after abdominal or hysteroscopic metroplasty or no surgical treatment. J Am Assoc Gynecol Laparosc. 1997;4:311-7.

3. Propst AM, Hill JA, 3rd. Anatomic factors associated with recurrent pregnancy loss. Semin Reprod Med. 2000;18:341-50.

4. Venetis CA, Papadopoulos SP, Campo R, Gordts S, Tarlatzis BC, Grimbizis GF. Clinical implications of congenital uterine anomalies: a meta-analysis of comparative studies. Reprod Biomed Online. 2014;29:665-83.

5. Uterine septum: a guideline. Fertil Steril. 2016;106:530-40.

6. Heinonen PK. Complete septate uterus with longitudinal vaginal septum. Fertil Steril. 2006;85:700-5.

7. Grimbizis GF, Camus M, Tarlatzis BC, Bontis JN, Devroey P. Clinical implications of uterine malformations and hysteroscopic treatment results. Hum Reprod Update. 2001;7:161-74.

8. Portuondo JA, Camara MM, Echanojauregui AD, Calonge J. Mullerian abnormalities in fertile women and recurrent aborters. J Reprod Med. 1986;31:616-9.

9. Pennisi E. DEVELOPMENTAL BIOLOGY. Using evolution to better identify cell types. Science. 2015;350:618-9.

10. Fedele L, Bianchi S, Marchini M, Franchi D, Tozzi L, Dorta M. Ultrastructura aspects of endometrium in infertile women with septate uterus. Fertil Steril. 1996;65:750-2.

11. Rackow BW, Arici A. Reproductive performance of women with mullerian anomalies. Curr Opin Obstet Gynecol. 2007;19:229-37.

12. Homer HA, Li TC, Cooke ID. The septate uterus: a review of management and reproductive outcome. Fertil Steril. 2000;73:1-14.

13. Fedele L, Dorta M, Brioschi D, Giudici MN, Candiani GB. Pregnancies in septate uteri: outcome in relation to site of uterine implantation as determined by sonography. AJR Am J Roentgenol. 1989;152:781-4. 